\title{
PEMODELAN PENENTUAN LOKASI STASIUN KOMPRESOR UNTUK PIPA TRANSMISI GAS DARI SUMATERA SELATAN - JAWA BARAT
}

\author{
Rena Amalika Asyari \\ Program Studi Manajemen Informatika, Politeknik Piksi Ganesha Bandung, Bandung, Indonesia \\ Email: rena.asyari@gmail.com
}

\begin{abstract}
Abstrak
Di dalam sistem pipa transmisi gas tentunya akan dipengaruhi oleh beberapa faktor baik itu luar maupun dalam. Faktor luar seperti pengaruh lingkungan luar juga topografi wilayah tersebut. Faktor internal seperti friksi, head loss dan lainnya. Tekanan yang diberikan di titik awal Stasiun, akan mengalami penurunan tekanan seiring dengan transmisi gas tersebut. Jika keadaan ini dibiarkan maka gas tidak akan sampai ke tempat tujuannya, jadi dibutuhkan suatu tenaga penggerak yang berfungsi menaikkan tekanan, hingga gas sampai ke tempat tujuannya. Tenaga penggerak yang dibutuhkan oleh gas yaitu berasal dari kompresor. Penentuan lokasi Stasiun kompresor didasarkan pada analisis hidrolik dari suatu sistem transmisi gas. Penelitian yang tertulis dalam tugas akhir ini adalah perhitungan untuk menentukan lokasi Stasiun kompresor yang efisien pada jaringan pipa transmisi dan distribusi gas berdasarkan pertimbangan penurunan tekanan akibat gesekan gas dengan dinding pipa. Pipa gas yang digunakan sebagai studi kasus adalah pipa transmisi dan distribusi gas dari Sumatera Selatan (Stasiun Grissik) - Jawa Barat (Muara Bekasi). Dengan melalui proses perhitungan, akan diperoleh lokasi dimana kompresor harus ditempatkan, tekanan keluar dari kompresor dan kapasitas kompresor yang harus digunakan.
\end{abstract}

Kata kunci: Gesekan, Kompresor, Maximum Allowable Working Pressure (MAWP)

\begin{abstract}
In the gas transmission pipe system definitely will be affected by several good factors was external and internal. The factor external like the influence of the outside environment also topography this territory. The internal factor like the friction, head loss and other. The pressure that was given in the point of the beginning the station, will experience the decline in the pressure together with the transmission of this gas. If this situation was allowed then gas will not arrive at his aim. So was needed by a functioning motive power increased the pressure, until gas arrived at his destination. The motive power that was needed by gas that is coming from the compressor. The determination of the location of the compressor station was based on the hydraulic analysis from a transmission system of gas. The research that was written in this thesis was the calculation to determine the location of the compressor station that was efficient in the network of the transmission pipe and the distribution of gas was based on consideration of the decline in the pressure resulting from the gas friction with the wall of the pipe. The gas pipe that was used as the case study was the transmission pipe and the distribution of gas from South Sumatra (the Grissik station) to West Java (the Muara Bekasi stasion). With through the process of the calculation, will be received the location where the compressor must be placed, the pressure left the compressor and the compressor capacity that must be used.
\end{abstract}

Keywords: Friction, Compressor, Maximum Allowable Working Pressure (MAWP)

\section{PENDAHULUAN}

Pada industri minyak dan gas (migas) di hulu, fluida yang diproduksi dari sumur-sumur di suatu lapangan migas tertentu salah satunya berupa gas alam. Gas alam tersebut harus dikumpulkan dan dibawa menuju fasilitas pemprosesan dan pemisahan, selanjutnya diteruskan hingga mencapai tempat penyimpanan akhir maupun konsumen secara langsung. Dengan semakin meningkatnya penggunaan gas, maka jaringan pipa yang dibutuhkan pun menjadi lebih besar dan lebih kompleks. Untuk itulah diperlukan adanya suatu metode perhitungan yang dapat melakukan analisa jaringan pipa yang kompleks tersebut.

Wilayah Indonesia yang terdiri dari kepulauan menyebabkan adanya pipa gas transmisi lintas pulau, yaitu dengan mengambil project pipa gas transmisi PT. Perusahaan Gas Negara (Persero) Tbk, pipa transmisi dari Pulau Sumatera (Grissik Station) ke Pulau Jawa (Muara Bekasi Station). Pipa merupakan suatu sarana yang ekonomis untuk produksi dan transmisi fluida dalam jumlah besar melalui jarak yang jauh. Pembuatan dan pemasangannya relatif mudah, serta jangka umur pemakaiannya cukup lama dengan biaya operasi yang cukup rendah. Dalam pendesainan suatu sistem jaringan pipa gas terdapat beberapa 
hal yang mempengaruhi, yaitu dari segi teknis dan non teknis. Segi teknis dalam hal ini adalah mengenai pendesainan jaringan pipa yang meliputi diameter pipa, panjang pipa, dan besarnya kompresor yang dibutuhkan. Sedangkan dari segi non teknis adalah pemilihan jalur pemasangan jaringan pipa itu sendiri.

Dalam mendesain jaringan pipa gas transmisi perlu juga diperhatikan penempatan kompresor yang akan digunakan sehingga dapat diperoleh daya kompresor yang dapat memenuhi kebutuhan dari segi teknis dan ekonomi. Dengan melakukan kombinasi parameter-parameter yang menunjang pembangunan jaringan pipa transmisi gas, antara lain jumlah kompresor yang digunakan dan penempatannya pada jaringan pipa tersebut.

\subsection{Sistem Pipa Transmisi Gas}

Transmisi gas merupakan penyaluran gas dari sumur gas menuju konsumen dengan menggunakan pipa, Sistem transmisi gas terdiri dari segmen pipa-pipa panjang yang disambung satu sama lain sehingga membentuk jalur pipa yang terhubung dari daerah sumber produksi gas bumi ke daerah konsumen. Sistem pipa transmisi untuk "Sumatra Selatan (Grissik) - Jawa Barat (Muara Bekasi) terbentang sejauh $625 \mathrm{KM}$, yang terdiri dari onshore (daratan) $464 \mathrm{Km}$ dan Offshore (lepas pantai) $101 \mathrm{Km}$, terbagi menjadi beberapa Stasiun penerima, ada 4 Stasiun penerima yaitu Stasiun Pagardewa, Stasiun Terbanggi Besar, Stasiun Labuhan Maringgai dan Stasiun Muara Bekasi, dan satu tambahan Stasiun penyalur yaitu Stasiun pertamina Pagardewa. Sistem transmisi dan distribusi gas ini dikelola oleh PT. Perusahaan Gas Negara (persero) Tbk., gas yang dialirkan tiap harinya mencapai 440 juta kubik (MMSCFD). Sistem transmisi dan distribusi gas mengalirkan gas ke beberapa Stasiun penerima yaitu Muara Bekasi, Serpong, Cikande, Bitung, Bojonegara dan Krakatau Steel.

Berikut ini adalah gambar sistem transmisi gas dari sumber sampai sampai ke Stasiun pemrosesan gas alam menggunakan jalur transmisi gas yang pada umumnya memiliki pipa berdiameter besar, lalu disalurkan kepada konsumen melalui sistem distribusi menggunakan jalur pipa berdiameter lebih kecil daripada jalur transmisi, karena jaringan pipa tersebut melewati kawasan penduduk. Sistem transmisi dan distribusi gas alam disajikan pada Gambar 1 .

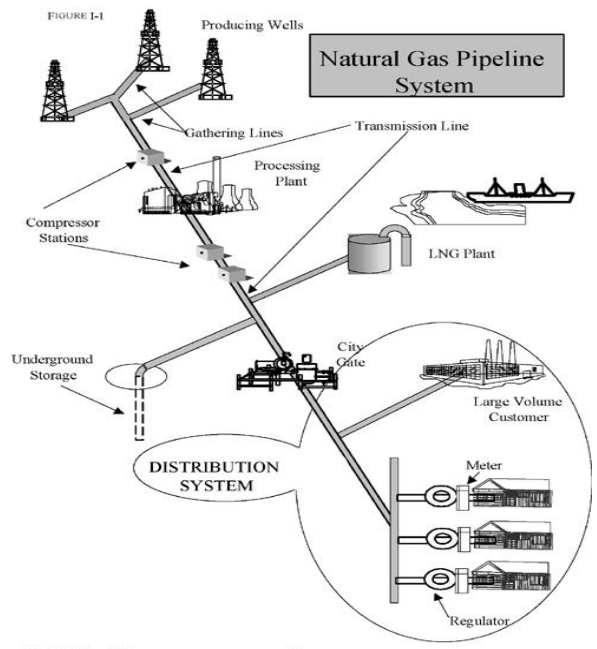

Gambar 1. Sistem Transmisi Dan Distribusi Gas Alam

\subsection{Kompresor}

Kompresor pada dasarnya bekerja memampatkan gas. Pemasangan kompresor di dalam sistem transportasi gas berfungsi untuk menaikan tekanan aliran gas sehingga gas dapat mengalir sampai ke konsumen dengan tekanan yang diinginkan. Jenis kompresor yang umum digunakan didalam sistem transportasi gas adalah kompresor sentrifugal. Kompresor ini menaikan tekanan gas dengan gaya sentrifugal yang ditimbulkan oleh impeller. Gas ditembakkan dengan kecepatan tinggi ke dalam suatu difusser, kemudian energi kinetik gas dikonversikan menjadi tekanan statik. Berdasarkan termodinamika ada 3 kompresi, isothermal, adiabatik, dan politropik, yang ideal isotermal dan adiabatik, dalam prakteknya perhitungan daya kompresi hanya memperhitungkan daya kompresi politropik saya yaitu kompresi yang terjadi pada gas nyata dibawah kondisi aktual akibat adanya gesekan dan transfer panas. 


\section{MATERI DAN METODE}

\subsection{Objek Penelitian}

Pada penelitian ini, objek yang diteliti yaitu pipa transmisi gas proyek PT. Perusahaan Gas Negara (Persero) Tbk, jalur pipa Sumatera - Jawa Barat, dengan menentukan penurunan tekanan, daya kompresor yang dibutuhkan, dan penempatan Stasiun kompresor yang tepat sehingga gas yang dapat sampai ke tempat tujuan sesuai dengan tekanan yang diinginkan. Metode yang digunakan dalam perhitungan yaitu metode Panhandle B.

\subsection{Sistem Transmisi Gas Sumatera - Jawa Barat}

Alur pipa transmisi dan distribusi gas, terbagi menjadi 2 phase yaitu, phase 1 dari Stasiun Pagardewa ke Stasiun Bojonegara (Cilegon), dan phase 2 yaitu dari Stasiun Grissik ke Stasiun Muara Bekasi. Alur pipa transmisi dan distribusi gas Sumatera Selatan - Jawa Barat disajikan pada Gambar 2.

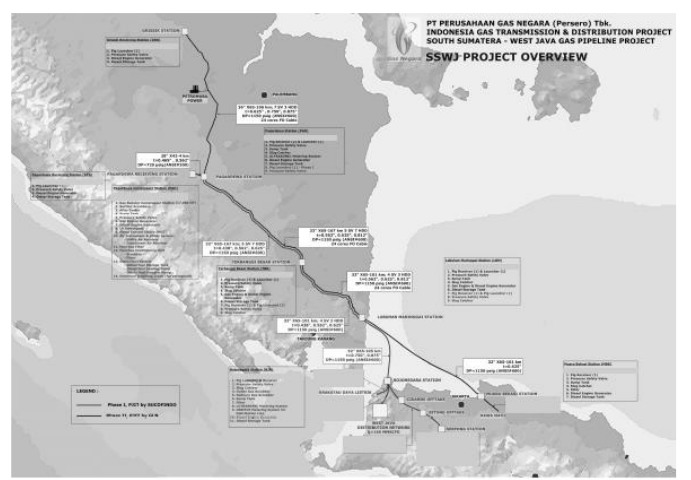

Gambar 2. Alur Transmisi dan Distribusi Gas Sumatera Selatan - Jawa Barat

Proyek pipa transmisi South Sumatera West Java (SSWJ) phase 2, panjang jalur ini mencapai 625 $\mathrm{km}$, dengan design pressure 1164.7 psia dan diameter pipa untuk Stasiun Grissik - Stasiun Pagardewa 36 inchi, Stasiun pertamina Pagardewa - Stasiun Pagardewa 28 inchi, dan untuk Stasiun Pagardewa Stasiun Muara Bekasi 32 inchi, dengan wall thikness berkisar antara 0.625 inchi. Jalur pipa transmisi ini dibagi menjadi 4 segmen yaitu, Stasiun Pertamina Pagardewa - Stasiun Pagardewa (4 km), Stasiun Grissik - Stasiun Pagardewa (196 km), Stasiun Pagardewa - Stasiun Labuhan Maringgai $(268$ km) dan offshore dari Stasiun Labuhan Maringgai - Stasiun Muara Bekasi (161 km).

Dimulai dengan tekanan sebesar 1064.7 psia di Stasiun Grissik maka gas mulai di transmisikan hingga menuju Stasiun Pagardewa, di Stasiun Pagardewa ini gas mengalami tambahan dari Stasiun pertamina pagardewa sebesar 514.7 psia, kemudian gas ditransmisikan terus hingga ke Stasiun Muara Bekasi, pada proses transmisi ini gas mengalami penurunan tekanan, sehingga butuh tenaga penggerak untuk menaikkan tekanan, berdasarkan perhitungan maka pemasangan kompresor pun dilakukan di lokasi Stasiun Pagardewa, dengan menggunakan 2 buah kompresor yang dipasang secara seri, dengan kapasitas yang berbeda. Diagram alur penelitian disajikan pada Gambar 3. 


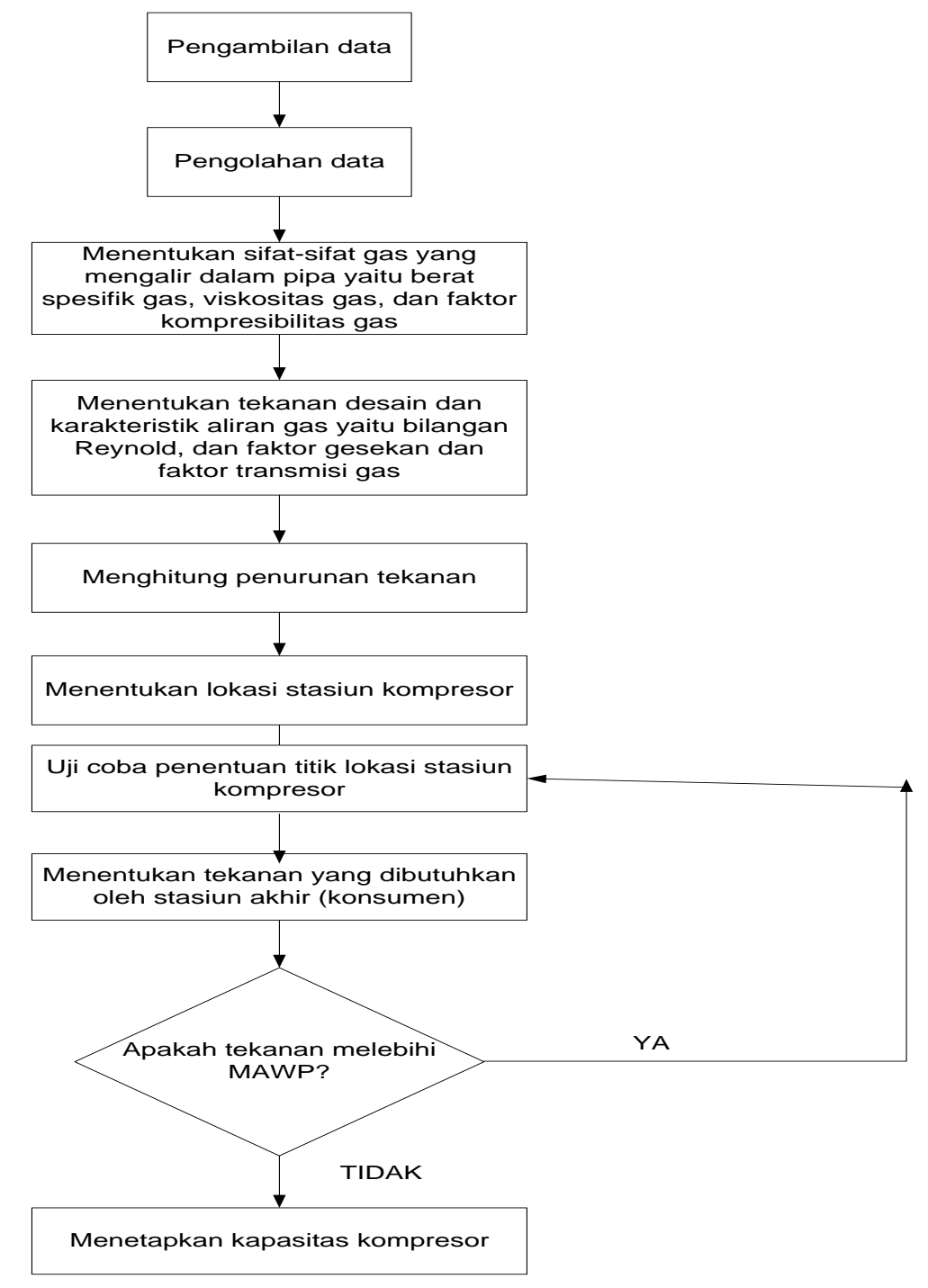

Gambar 3. Diagram Alur Penelitian

\subsection{Studi Literatur}

Studi literatur dilakukan terhadap sifat-sifat gas, berat molekular gas, kerja kompresor dari berbagai sumber seperti buku-buku, jurnal-jurnal, artikel-artikel, dan bahan tertulis lainnya. Studi literatur ini dilakukan untuk menunjang teori-teori serta acuan-acuan dasar untuk menentukan pemilihan kompresor dan penentuan lokasi yang sesuai dengan karakteristik gas yang dialirkan dalam pipa.

\subsection{Pengambilan Data}

Data yang digunakan berupa data sekunder yang diperoleh dari PT. Perusahaan Gas Negara (Persero) Tbk, Indonesia Gas Transmission \& Distribution Project, South Sumatera - West Java Gas Pipeline Project 2008. Data-data tersebut berupa data komponen gas, panjang pipa, tekanan awal, dan tekanan akhir - MAWP, karakteristik umum gas (seperti specific gravity, viskositas, kompresibilitas gas, dan laju alir), serta diameter, ketebalan, dan jenis pipa. Untuk penentuan penurunan tekanan pada pipa transmisi gas digunakan data literatur Gas Pipeline Hidraulics.

\subsection{Pengolahan Data dan Perhitungan}

Data yang diperoleh kemudian diolah dengan menggunakan perangkat lunak Microsoft Excel. Melakukan perhitungan terhadap sifat-sifat gas yang mengalir dalam pipa, seperti menentukan specific graviti gas, viskositas gas dan faktor kompresibilitas gas, kemudian menghitung karakteristik aliran gas dalam pipa, seperti menghitung bilangan Reynold, faktor gesekan dan faktor transmisi gas. 
Setelah mendapatkan gambaran mengenai panjang lintasan pipa, lalu dilakukan perhitungan terhadap penurunan tekanan. Proyek Sumatera Selatan-Jawa Barat ini terbagi menjadi beberapa lokasi Stasiun penerima, penurunan tekanan dihitung untuk masing-masing Stasiun penerima. Langkah selanjutnya yang dilakukan adalah menentukan lokasi Stasiun kompresor. Setelah estimasi lokasi diperoleh, lalu dilakukan uji coba terhadap hasil ini. Apakah tekanan yang dibutuhkan tidak melebihi MAWP. Jika melebihi MAWP maka penentuan lokasi belum tepat. Namun jika kurang dari atau sama dengan MAWP maka lokasinya sudah sesuai.

\section{HASIL DAN PEMBAHASAN}

3.1 Pengolahan Data Stasiun Grissik - Stasiun Pagardewa

Menentukan Press Drop dengan Jarak 20 km

Untuk dapat menghitung nilai press drop kita harus mengetahui terlebih dahulu tekanan awal $\left(\mathrm{P}_{1}\right)$ dan tekanan akhirnya $\left(\mathrm{P}_{2}\right)$. Perhitungan ini dilakukan untuk mengetahui seberapa besar penurunan tekanan yang terjadi, dengan jarak setiap $20 \mathrm{Km}$. Dengan menggunakan rumus $\Delta P=P_{1}-P_{2}$, maka didapatkan hasil perhitungan press drop. Hasil perhitungan pressure drop disajikan pada Tabel 1 dan gambar 4 .

Tabel 1. Hasil Perhitungan Pressure Drop tiap $20 \mathrm{Km}$

\begin{tabular}{ccccc}
\hline $\mathbf{K m}$ & $\mathbf{M i}$ & $\mathbf{P 1}$ & $\mathbf{P 2}$ & $\Delta \mathbf{P}$ \\
\hline 0 & 0 & 1064.7 & 1064.7 & 0 \\
20 & 12.4 & 1064.7 & 1022.09 & 42.61 \\
40 & 24.8 & 1022.09 & 977.623 & 44.467 \\
60 & 37.2 & 977.623 & 931.035 & 46.588 \\
80 & 49.6 & 931.035 & 881.99 & 49.045 \\
100 & 62 & 881.99 & 830.05 & 51.94 \\
120 & 74.4 & 830.05 & 774.64 & 55.41 \\
140 & 86.8 & 774.64 & 714.95 & 59.69 \\
160 & 99.2 & 714.95 & 649.79 & 65.16 \\
180 & 111.6 & 649.79 & 577.33 & 72.46 \\
196 & 121.52 & 577.33 & 511.27 & 65.3 \\
\hline
\end{tabular}

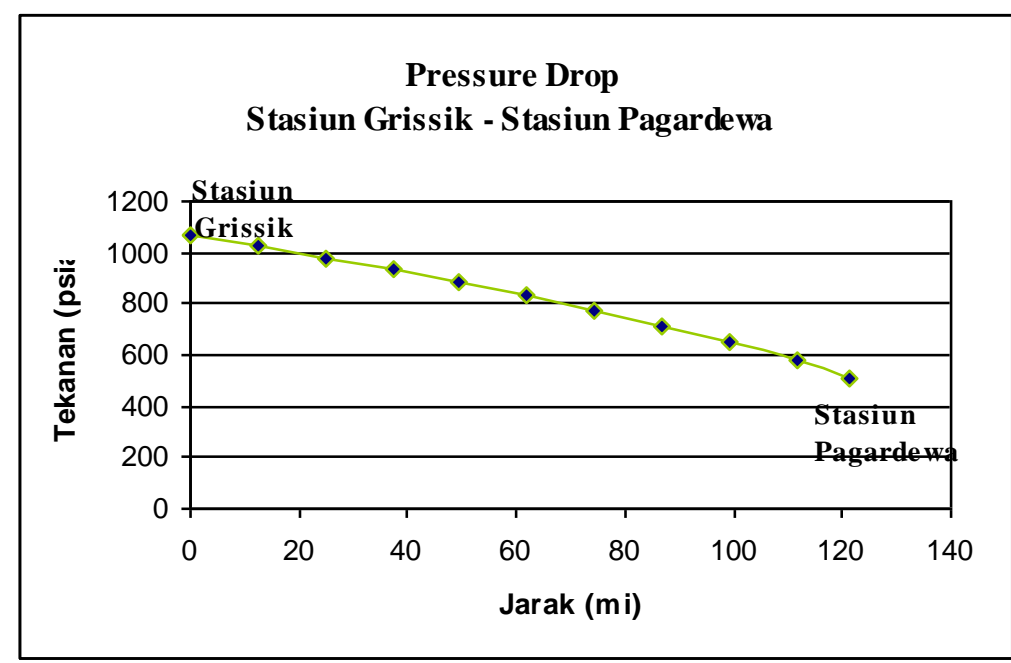

Gambar 4. Pressure Drop Stasiun Grissik - Stasiun Pagardewa 


\subsection{Pengolahan Data Stasiun Pagardewa - Stasiun Labuhan Maringgai}

Menghitung Nilai Press Drop Setiap 20 Km

Hitungan press drop setiap $20 \mathrm{~km}$ disajikan pada Tabel 2 dan gambar 5.

Tabel 2. Hasil Perhitungan Press Drop tiap $20 \mathrm{Km}$

\begin{tabular}{ccccc}
\hline $\mathbf{K m}$ & $\mathbf{m i}$ & $\mathbf{P 1}$ & $\mathbf{P 2}$ & $\Delta \mathbf{P}$ \\
\hline 0 & 0 & 511.27 & 511.27 & 0 \\
20 & 12.4 & 511.27 & 492.48 & 19.55 \\
40 & 24.8 & 492.48 & 472.12 & 20.36 \\
60 & 37.2 & 472.12 & 450.83 & 21.29 \\
80 & 49.6 & 450.83 & 428.5 & 22.33 \\
100 & 62 & 428.5 & 404.94 & 23.56 \\
120 & 74.4 & 404.94 & 379.92 & 25.02 \\
140 & 86.8 & 379.92 & 353.12 & 26.8 \\
160 & 99.2 & 353.12 & 324.12 & 29 \\
180 & 111.6 & 324.12 & 292.26 & 31.86 \\
200 & 124 & 292.26 & 256.47 & 35.79 \\
220 & 136.4 & 256.47 & 214.79 & 41.68 \\
240 & 148.8 & 214.79 & 162.78 & 52.01 \\
268 & 166.16 & 162.78 & 129.14 & 33.64 \\
\hline
\end{tabular}

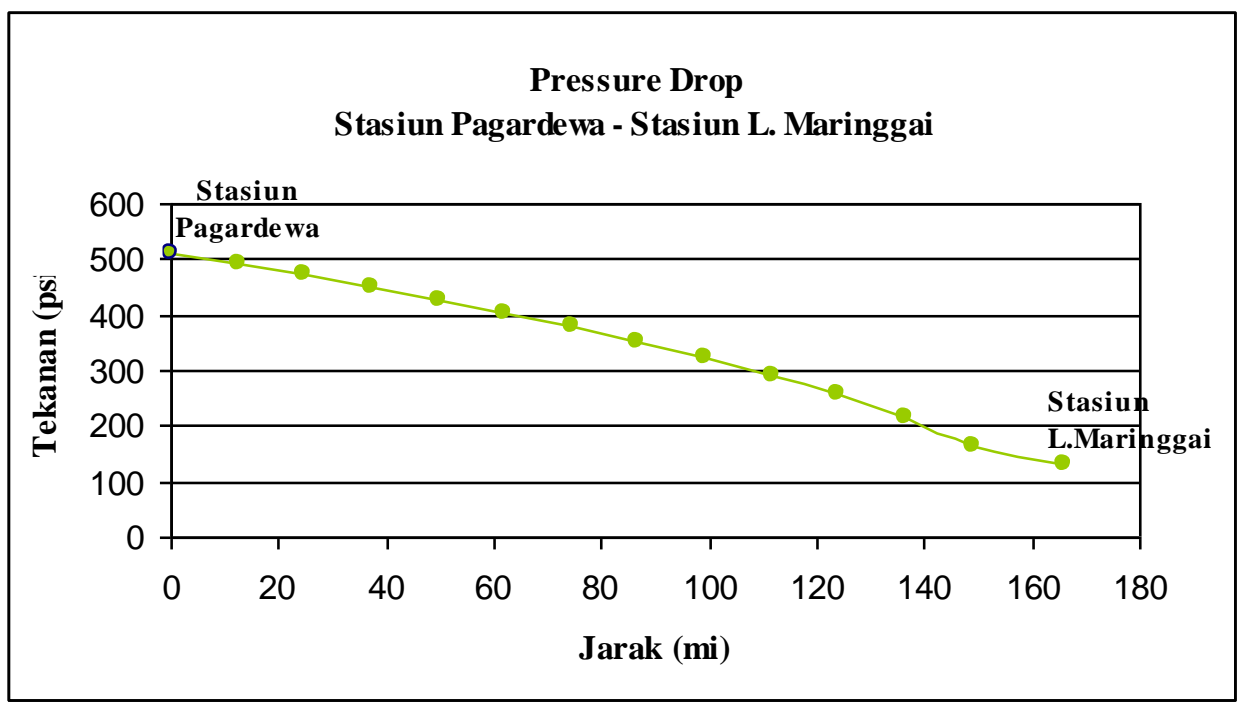

Gambar 5. Pressure Drop Stasiun Pagardewa - Stasiun Labuhan Maringgai

\subsection{Penentuan Lokasi Kompresor}

Setelah penurunan tekanan diketahui, langkah selanjutnya adalah mencegah agar tekanan tidak jatuh di bawah tekanan yang diinginkan di lokasi penerima (Stasiun Muara Bekasi). Terlihat pada perhitungan dan pada grafik, tekanan yang sampai di lokasi Stasiun Labuhan Maringgai, sekitar 129 psia, perhitungan penurunan tekanan selanjutnya untuk Stasiun Muara Bekasi tidak dapat dilakukan, karena tekanan pada Stasiun sebelumnya (Stasiun Labuhan Maringgai) sangat kecil. Untuk itu dilakukan penempatan kompresor untuk menaikkan tekanan.

Dalam penentuan lokasi Stasiun kompresor, digunakan prinsip kesetimbangan hidrolik yaitu uji coba penentuan titik lokasi Stasiun hidrolik. Tekanan mengalami penurunan yang sangat besar terlihat pada kurva yaitu pada $124 \mathrm{mi}$, berada disekitar Stasiun Pagardewa, tekanan mengalami penurunan sebesar 82.97 psia. Penurunan tekanan dihitung setiap jarak $20 \mathrm{~km}$ atau $12.4 \mathrm{mi}$. Perhitungan gabungan pressure drop ari Stasiun Grissik - Stasiun Labuhan Maringgai disajikan pada Tabel 3 dan gambar 6. 
Tabel 3. Tabel Gabungan Perhitungan Pressure Drop

(Stasiun Grissik - Stasiun Labuhan Maringgai)

\begin{tabular}{ccccc}
\hline $\mathbf{K m}$ & $\mathbf{M i}$ & $\mathbf{P 1}$ & $\mathbf{P 2}$ & $\Delta \mathbf{P}$ \\
\hline 0 & 0 & 1064.7 & 1064.7 & 0 \\
20 & 12.4 & 1064.7 & 1022.09 & 42.61 \\
40 & 24.8 & 1022.09 & 977.623 & 44.467 \\
60 & 37.2 & 977.623 & 931.035 & 46.588 \\
80 & 49.6 & 931.035 & 881.99 & 49.045 \\
100 & 62 & 881.99 & 830.05 & 51.94 \\
120 & 74.4 & 830.05 & 774.64 & 55.41 \\
140 & 86.8 & 774.64 & 714.95 & 59.69 \\
160 & 99.2 & 714.95 & 649.79 & 65.16 \\
180 & 111.6 & 649.79 & 577.33 & 72.46 \\
200 & 124 & 577.33 & 494.36 & 82.97 \\
220 & 136.4 & 494.36 & 492.48 & 1.88 \\
240 & 148.8 & 492.48 & 472.12 & 20.36 \\
260 & 161.2 & 472.12 & 450.83 & 21.29 \\
280 & 173.6 & 450.83 & 428.5 & 22.33 \\
300 & 186 & 428.5 & 404.94 & 23.56 \\
320 & 198.4 & 404.94 & 379.92 & 25.02 \\
340 & 210.8 & 379.92 & 353.12 & 26.8 \\
360 & 223.2 & 353.12 & 324.12 & 29 \\
380 & 235.6 & 324.12 & 292.26 & 31.86 \\
400 & 248 & 292.26 & 256.47 & 35.79 \\
420 & 260.4 & 256.47 & 214.79 & 41.68 \\
440 & 272.8 & 214.79 & 162.78 & 52.01 \\
464 & 287.68 & 162.78 & 129.14 & 33.64 \\
\hline
\end{tabular}

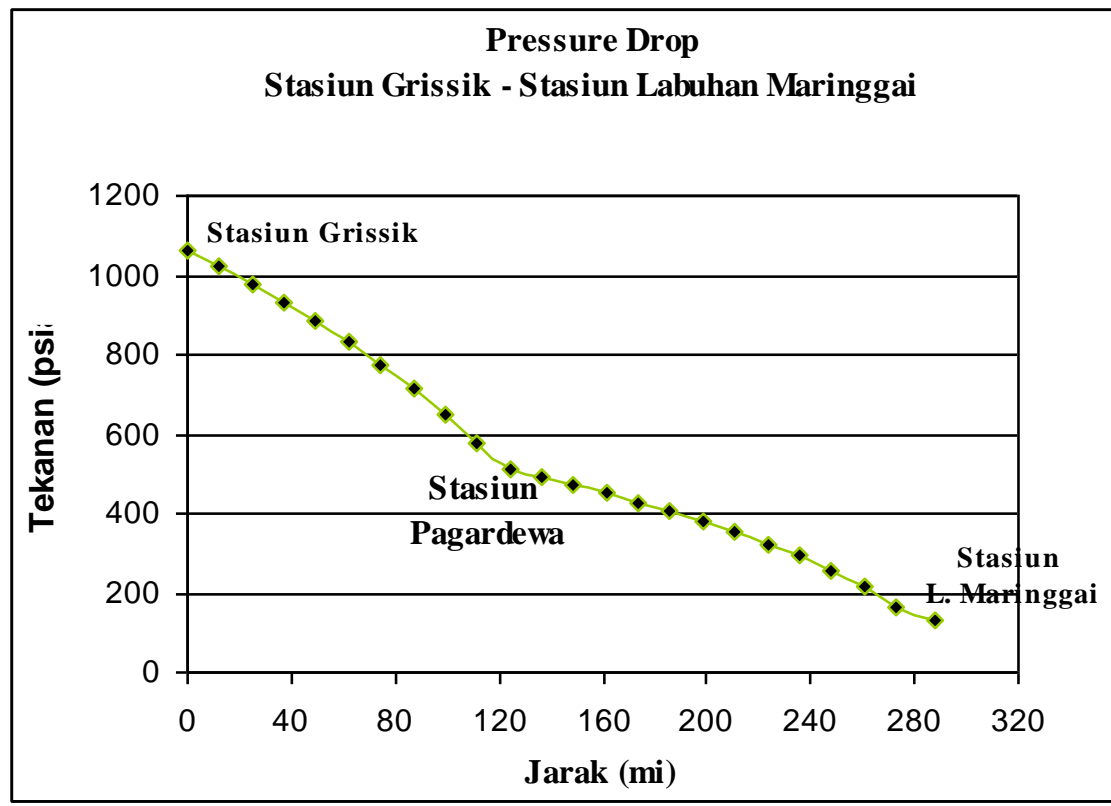

Gambar 6. Pressure Drop Gabungan Stasiun Grissik - Stasiun Labuhan Maringgai (sebelum ditambahkan kompresor) 


\section{a. Perhitungan penentuan Lokasi Stasiun Kompresor}

Dengan menggunakan persamaan :

$$
\begin{aligned}
& \Delta P=7.0631 \frac{\mu^{0.0392} \rho^{0.9608}\left(\frac{Z . T_{a v g}}{P_{a v g}} Q_{g}\right)^{1.9608} L}{D o p t^{4.9608}} x\left(\frac{1}{144}\right) \\
& \Delta P=P_{1}-P_{2} \\
& \text { Diketahui bahwa : } \quad=1064.7-129.14 \\
& =935.56 \text { psia } \\
& \Delta P=0.644 L \\
& 935.56=0.644 \mathrm{~L} \\
& L=602.02 f t \\
& L=114 m i
\end{aligned}
$$

Setelah dilakukan perhitungan maka diperoleh hasil bahwa penempatan Stasiun kompresor di Stasiun Pagardewa yaitu pada jarak 114 mi dari Stasiun Grissik. Tekanan sebelum diberikan kompresor sekitar 570 psia, setelah diberikan tenaga penggerak yaitu kompresor maka tekanan naik sampai dibawah batas MAWP yaitu 1064.7 psia. Pressure drop gabungan Stasiun Grissik - Stasiun Labuhan maringgai disajikan pada gambar 7.

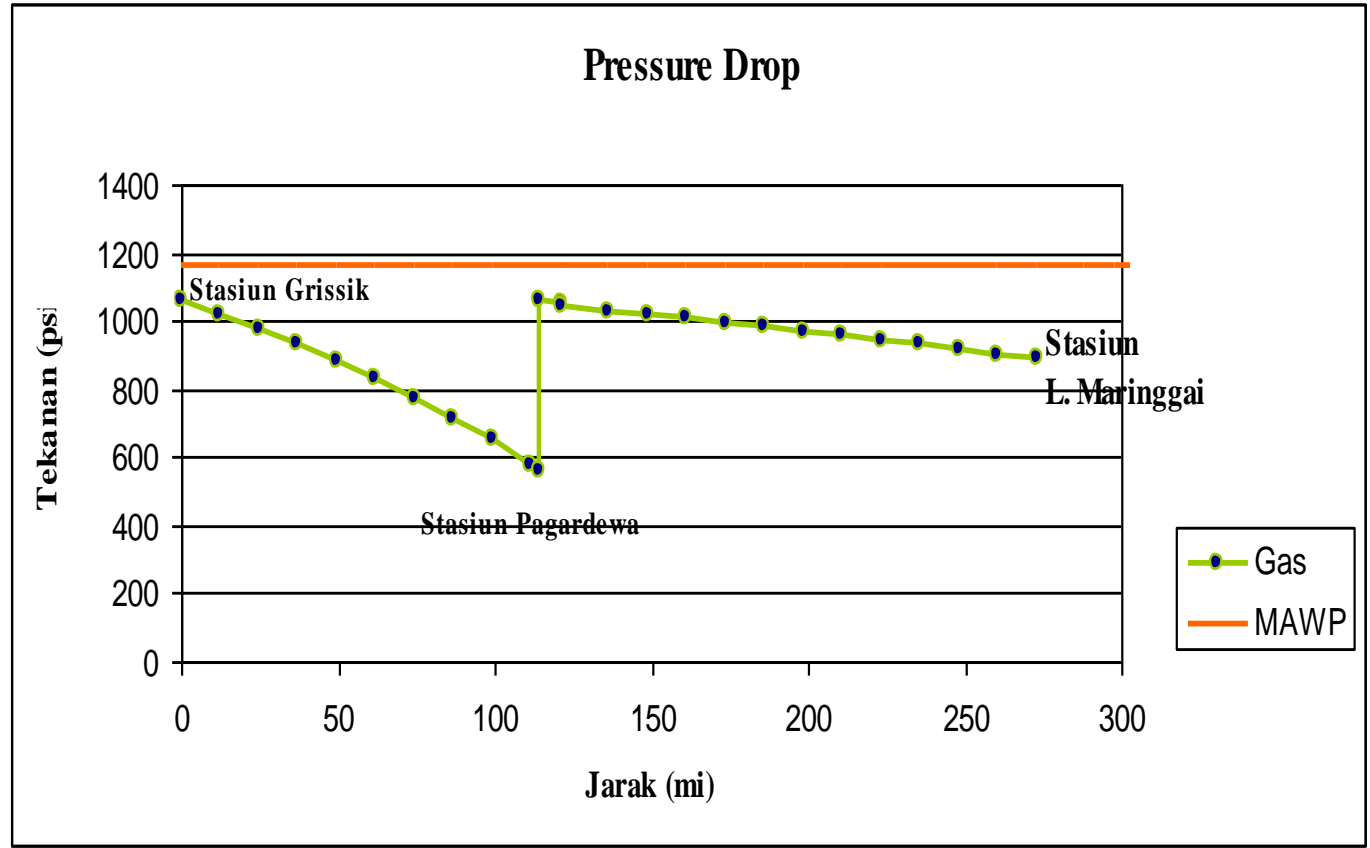

Gambar 7. Pressure Drop Gabungan Stasiun Grissik - Stasiun Labuhan Maringgai (setelah ditambahkan kompresor)

\subsection{Menghitung Daya Kompresor}

Kompresor berfungsi untuk menaikkan tekanan, dibutuhkan daya kompresor yang sesuai agar tekanan yang sampai pada konsumen sesuai dengan yang dibutuhkan. Penempatan kompresor seperti telah dihitung diatas yaitu dilokasi 114 mi dari Stasiun Grissik, pada jarak tersebut tekanan yang dimiliki yaitu sekitar 560 psia, maka tekanan tersebut bisa disebut tekanan discharge kompresor, sedangkan tekanan suctionnya yaitu tekanan awal dari Stasiun Grissik berkisar 1064,7 psia. 
a. Menghitung nilai efisiensi polytropic

Dengan menggunakan rumus :

$$
\begin{aligned}
\eta_{p 1} & =\frac{K-1}{K} \cdot \frac{n}{n-1} & \eta_{p 2} & =\frac{K-1}{K} \cdot \frac{n}{n-1} \\
& =\frac{1.3-1}{1.3} \cdot \frac{1.34}{1.34-1} & & =\frac{1.3-1}{1.3} \cdot \frac{1.42}{1.42-1} \\
& =0.9 & & =0.78
\end{aligned}
$$

Dimana : $\quad \eta p=$ efisiensi polytropic

$$
\begin{aligned}
& \mathrm{K}=\text { eksponen gas adiabatic (nilai asumsi) } \\
& \mathrm{n}=\text { eksponen gas polytropic }
\end{aligned}
$$

\section{b. Perhitungan Daya kompresor}

Dengan menggunakan rumus :

$$
H P=0.0857 \cdot \frac{n}{n-1} \cdot Q \cdot T_{1} \cdot Z_{1} \cdot \frac{1}{\eta p}\left[\left(\frac{P_{2}}{P_{1}}\right)^{\frac{n-1}{n}}-1\right]
$$

Maka didapat hasil :

$$
\begin{aligned}
H P_{1} & =0.0875 \cdot \frac{1.34}{1.34-1} \cdot 440.520 \times 0.9 \times \frac{1}{0.9}\left[\left(\frac{750}{560}\right)^{\frac{1.34-1}{1.34}}-1\right] \\
& =6070 \\
H P_{2} & =0.0875 \cdot \frac{1.42}{1.42-1} \cdot 440.520 \times 0.9 \times \frac{1}{0.78}\left[\left(\frac{1064.7}{750}\right)^{\frac{1.42-1}{1.42}}-1\right] \\
& =8527
\end{aligned}
$$

\subsection{Pengolahan Data Stasiun Muara Bekasi}

Setelah penentuan lokasi kompresor maka perhitungan tekanan dilanjutkan hingga ke lokasi akhir yaitu Stasiun Muara Bekasi. Sistem transmisi dari Stasiun Labuhan Maringgai ke Stasiun Muara Bekasi berupa offshore. Profile kedalaman air dapat terlihat pada gambar 8.

Dengan membaginya menjadi 3 titik, yaitu di titik $0 \mathrm{~km}$ kedalaman 0 meter, lalu di titik $110 \mathrm{Km}$ kedalaman $85 \mathrm{~m}$, dan titik akhir $161 \mathrm{Km}$ kedalaman 0 meter maka dapat ditentukan nilai pressure dropnya.

a. Perhitungan nilai $\mathbf{P}_{2}$ :

$$
\begin{aligned}
& Q=33.78 F\left(\frac{T_{b}}{P_{b}}\right)\left(\frac{P_{1}^{2}-e^{5} P_{2}^{2}}{G T_{f} L_{e} Z}\right)^{0.5} D^{2.5} \\
& 440=38.77 \times 24.04 \times\left(\frac{520}{14.7}\right)\left(\frac{875^{2}-2.718^{0.0134} \times P_{2}^{2}}{0.6 \times 560 \times 31.62 \times 0.9}\right)^{0.5} 30.75^{2.5} \\
& P_{2}=863.55 \text { psia }
\end{aligned}
$$

Dengan perhitungan yang telah dilakukan maka dapat ditarik kesimpulan bahwa jumlah tekanan yang dapat sampai ke konsumen berkisar antara 863 psia. Kurva pressure drop gabungan dari Stasiun Grissik - Stasiun Muara Bekasi disajikan pada Gambar 8. 


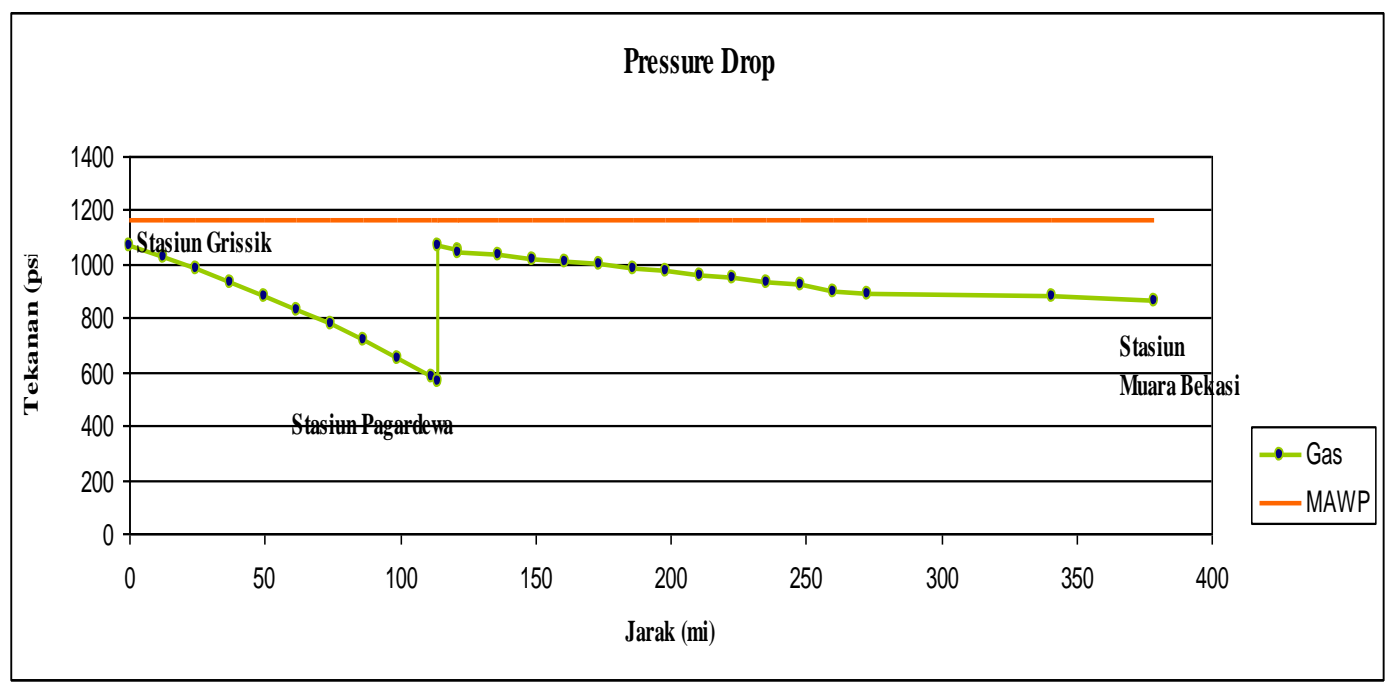

Gambar 8. Kurva Pressure Drop Stasiun Grissik - Stasiun Muara Bekasi

\subsection{Perhitungan Prosentase Penurunan Tekanan}

Penurunan tekanan akan terjadi dalam perjalanan suatu sistem pipa transmisi, itu disebabkan beberapa faktor salah satunya adalah faktor gesekan. Prosentase penurunan tekanan disajikan pada tabel 4 dan tabel 5.

Tabel 4. Prosentase Penurunan Tekanan

\begin{tabular}{ccc}
\hline Lokasi & $\Delta \mathbf{P}$ & $\mathbf{\%}$ \\
\hline Stasiun Grissik - Stasiun Pagardewa & 553.47 & 51.98 \\
Stasiun Pagardewa - Stasiun Labuhan Maringgai & 177.7 & 16.69 \\
Stasiun Labuhan Maringgai - Stasiun Muara Bekasi & 24 & 2.71 \\
\hline
\end{tabular}

Tabel 5. Rasio dan Daya Kompresor

\begin{tabular}{ccc}
\hline KOMPRESOR & $\mathbf{1}$ & $\mathbf{2}$ \\
\hline Rasio & 0.9 & 0.78 \\
Daya & 6070 & 8527 \\
\hline
\end{tabular}

\section{KESIMPULAN}

a. Laju aliran gas dalam pipa transmisi dipengaruhi oleh beberapa faktor diantaranya yaitu diameter, specifik grafity, viskositas, jarak dan sifat fisik gas itu sendiri, karena semakin banyak gas yang dialirkan maka friksinya juga akan semakin besar, jika friksi semakin besar maka diperlukan pipa dengan desain yang kuat, tekanan yang diberikan tidak boleh melebihi Maximum Allowable Working Pressure (MAWP)

b. Dalam perjalanannya gas akan mengalami penurunan tekanan, hal ini seiring dengan bertambahnya panjang pipa dan friksi yang terjadi.

c. Untuk mengatasi penurunan tekanan maka ditempatkan sebuah kompresor yang berufungsi untuk menaikkan tekanan, berdasarkan perhitungan, kompresor diletakkan di jarak 114 mi dari Stasiun Grissik, pada jarak ini, perbandingan rasio tekanan memungkinkan pemasangan 2 buah kompresor yang dipasang secara seri dengan kapasitas $6070 \mathrm{HP}$ dan $8527 \mathrm{HP}$. 


\section{REFERENSI}

1. Ikoku, C.U. 1984. Natural Gas Production Engineering. New York : John Willey \& Sons Inc.

2. Liu, Henry.2003. Pipeline Engineering. Newyork : Taylor and Francis Group

3. Murray,A., Golshan, H., Mohitpour, M. 2003. Pipeline Design \& Construction : A Practical Approach. Second Edition. New York : Three Park Avenue

4. Menon, E. Shashi. 2005. Gas Pipeline Hydraulics. Newyork : Taylor and Francis Group

5. Pipeline Technical Data, PT. Perusahaan Gas Negara Tbk, (Persero), Indonesian Transmission and Distribution Project South Sumatera - West Java Gas Pipeline Project 2008.

6. The American Society Of Mechanical Engineers. 2002. ASME B31.4: Pipline Transportation Systems For Liquid Hydrocarbons And Other Liquids. USA: Global Engineering Documents.

7. Specification For Line Pipe, API SPECIFICATION 5L FORTY- SECOND EDITION, JANUARY 2000 